University of Nebraska - Lincoln

DigitalCommons@University of Nebraska - Lincoln

Communication Studies Theses, Dissertations, and Student Research

Communication Studies, Department of

$1-2012$

\title{
"If You Can Dream It, You Can Achieve It." Parent Memorable Messages as Indicators of College Student Success
}

Haley Kranstuber

University of Nebraska-Lincoln, haley.kranstuber@huskers.unl.edu

Kristen Carr

University of Nebraska-Lincoln, kristencarr@huskers.unl.edu

Angela M. Hosek

Emerson College, angela_hosek@emerson.edu

Follow this and additional works at: https://digitalcommons.unl.edu/commstuddiss

Part of the Communication Commons

Kranstuber, Haley; Carr, Kristen; and Hosek, Angela M., "'If You Can Dream It, You Can Achieve It." Parent Memorable Messages as Indicators of College Student Success" (2012). Communication Studies Theses, Dissertations, and Student Research. 19.

https://digitalcommons.unl.edu/commstuddiss/19

This Article is brought to you for free and open access by the Communication Studies, Department of at DigitalCommons@University of Nebraska - Lincoln. It has been accepted for inclusion in Communication Studies Theses, Dissertations, and Student Research by an authorized administrator of DigitalCommons@University of Nebraska - Lincoln. 


\title{
"If You Can Dream It, You Can Achieve It." Parent Memorable Messages as Indicators of College Student Success
}

\author{
Haley Kranstuber, Kristen Carr, and Angela M. Hosek
}

\begin{abstract}
This study investigated various aspects of parents' memorable messages about college as they relate to indicators of college student success. Findings revealed that parents' memorable messages about college focused on working (and playing) hard, the necessity of attending college, providing encouragement and support, and general advice based on parents' own experiences. Although these message themes were not uniquely predictive of college student success, the students' perceptions of message and sender characteristics emerged as significant predictors of cognitive learning indicators, learner empowerment, college motivation, and satisfaction with college. Theoretical and practical implications for findings are discussed.
\end{abstract}

Keywords: parent communication, memorable messages, college student success

Most Americans agree that obtaining a college education is a necessity for success (Immerwahr, Johnson, Ott, \& Rochkind, 2010), and research supports this contention (e.g., Bureau of Labor Statistics, 2011). However, despite the benefits of college graduation, $30 \%$ of college students drop out in their first year, and $56 \%$ do not complete their degrees (National Center for Education Statistics [NCES], 2008). The disparity between the importance of college success and the rates of achievement is staggering, making research on the various factors that contribute to success in college both important and timely.

\footnotetext{
Haley Kranstuber (M.A., Miami University, 2008) and Kristen Carr (M.S., Texas Christian University, 2009) are a doctoral students in the Department of Communication Studies at the University of NebraskaLincoln. Angela M. Hosek (Ph.D., University of Nebraska-Lincoln, 2011) is a faculty member in the Department of Communication Studies at Emerson College. The authors would like to thank Bill Seiler and Jenn Anderson for their counsel on the manuscript, and Colleen Colaner and Sai Sato Mumm for their assistance in coding the data. All correspondence should be directed to the first author at: Department of Communication Studies, University of Nebraska-Lincoln, 433 Oldfather Hall, Lincoln, NE 68588-0329, haley.kranstuber@huskers.unl.edu
} 
Instructional communication researchers have developed a large body of literature to better understand the factors associated with college student success, including teacher immediacy (Frymier, 1994), student motivation (Christophel, 1990), teaching methods (Muddiman \& Frymier, 2009) and affinity-seeking (Frymier \& Wanzer, 2006). Although this knowledge is important, we are less aware of the outside factors influencing students' success, such as communication in the family. Students enter the classroom with a wide range of experiences and perspectives, and researchers must acknowledge and seek to understand these influences (Sprague, 1992, 2002). Thus, we turn to one of the most influential sources of a person's understanding of the world - the family.

Researchers have found a direct relationship between family characteristics (e.g., race, socioeconomic status, parent education) and rates of college graduation (NCES, 2001), yet these are not the only familial factors with the potential to influence students' college success. Family demographic information fails to account for the communicative processes that occur within families; indeed, numerous researchers point to the vital role that parents' behaviors play in fostering children's academic success (Alwin \& Thornton, 1984; Dauber \& Epstein, 1993; Smith \& Butler Ellis, 2001). Parents are highly influential in children's education decisions (Grolnick \& Slowiaczek, 1994; Hoover-Dempsey \& Sander, 1995) and attitudes toward school (Dauber \& Epstein, 1993). The messages that parents provide to their children influence values, perspectives, and behaviors throughout their children's lifetime (Knapp, Stohl, \& Reardon, 1981; Smith \& Butler Ellis, 2001). College students receive advice about navigating college from family members (including parents), academic personnel, friends, and the media (Nanzione, Laplante, Smith, Cornacchione, Russell, \& Stohl, 2001), and overall messages students receive from important others are predictive of their success in school (Cauce, Hannan, \& Sargeant, 1992).

Although research has shown that parental behaviors are predictive of children's academic success and that parents provide memorable messages to their children about college, the relationship between specific parent messages and college student success remains unclear. Thus, the purpose of this study was to understand how students make sense of the messages they receive from their parents about the college experience and how, if at all, those messages predict outcomes of college success. To accomplish this goal, we first explored the ways in which parents can use memorable messages to aid students' sense-making about college.

\section{Influence of Family Socialization Through Memorable Messages}

Family communication helps to construct and enforce family and individual identities (Galvin, 2003; Stone, 1988), provides "social knowledge" that guides individuals' decisions, and perpetuates this social knowledge from one generation to the next (Medved, Brogan, McClanahan, Morris, \& Shepherd, 2006). Because this process is both mutual and continual, social roles are not simply defined and fulfilled; rather, they are co-constructed through family communication 
(e.g., Fitzpatrick \& Caughlin, 2002). Although family socialization can occur between various family members, one of the most influential socializing relationships exists between parents and children (Smith \& Butler Ellis, 2001). A significant body of research depicts the ways in which parents socialize their children toward particular worldviews through shaping their orientation toward life activities such as work and organizations (e.g., Lucas, 2011; Medved et al., 2006). Although socialization occurs in a variety of ways, one of the most common and influential means is through direct communication between parents and children (Vangelisti, Crumley \& Baker, 1999). Therefore, it is important to examine how parents' messages about college help students make sense of their lives. One type of enduring socialization exists in memorable messages children receive from their parents.

Memorable messages and college success. In their foundational work on memorable messages, Knapp et al. (1981) conceptualized memorable messages as verbal messages that people remember, hear relatively early in life, and consider influential in some way. People reported receiving these messages at critical, important, and/or confusing times in their life, often when they were seeking guidance in order to make sense of a situation. Memorable messages may be acted on in the moment, but are usually remembered and "pulled forward" for sense-making, particularly in transitional and confusing moments in one's life (Medved et al., 2006). Family memorable messages have been identified as influential to individuals' relational worldviews (Knapp et al., 1981), body image satisfaction (Catlett \& Koenig Kellas, Koenig Kellas, 2009), views on aging (Holladay, 2002), and education and careers (Knapp et al., 1981; Medved et al., 2006; Nanzione et al., 2001). Several studies have found that families deliver explicit memorable messages to their children about their future careers (Lucas, 2011; Medved et al., 2006), and impact individuals' career decisions when entering college (Lucas, 2011; Nanzione et al., 2001). College students have indicated that the majority of their memorable messages about college came from their parents, and they perceived these memorable messages as an important influence to their behavior (Nanzione et al., 2001). However, scholars have not yet examined the impact of these messages on college success.

Given that memorable messages are often invoked at times of decision-making and sense-making (Knapp et al., 1981; Medved et al., 2006), students may recall these messages during college, which is a transitional and often difficult time in life (Eckel, 1994; Nanzione et al., 2001). Understanding the connection between memorable messages, sense-making, and college success may illuminate the complexities of students' sense-making and behaviors that impact their success in college. We began our investigation of the influence of parental memorable messages on college success by seeking to determine the nature of the messages students receive from their parents about college. Thus, we posed the following research question:

RQ: What types of memorable messages about college do students receive from their parents? 
In addition to identifying the types of messages students receive that help them make sense of the college experience, it is important to understand how these messages influence student success. There is increasing recognition that "both school and home are important institutions that socialize and educate children" (Grolnick \& Slowiaczek, 1994, p. 237). Researchers have demonstrated the centrality of family demographic characteristics and parental involvement in predicting students' academic achievement; yet they have largely neglected to highlight the ways in which communication in the family account for students' academic success. Parental involvement has been found to be predictive of academic achievement in children (Chen, Yu, \& Chang, 2007; Cutrona, Cole, Colangelo, Assouline, \& Russell, 1994; McKay, Atkins, Hawkins, Brown, \& Lynn, 2003); and children, regardless of grade level, are more successful academically when their parents are involved in their education (Dauber \& Epstein, 1993; Desmione, 1999; Griffith, 1996; Thorkildsen \& Stein, 1998).

Likewise, instructional communication scholars have largely focused on the impact of teacher communication behaviors on college student success. Because much of this research has been conducted within the realm of the teacher-student interpersonal relationship, these findings may inform our investigation as to how the parent-student relationship influences college student success. Namely, many instructional researchers argue that the teacher-student relationship can be seen as an interpersonal relationship (e.g., Docan-Morgan \& Manusov, 2009; Frymier \& Houser, 2000; Hosek \& Thompson, 2009), and like other interpersonal relationships (e.g., parent-child), it is characterized by mutual influence (Mottet, Martin, \& Myers, 2004). Teacher communication behaviors have been shown to influence student learning, feelings of satisfaction, motivation, and empowerment (e.g., Chesebro \& McCroskey, 2000; Frymier \& Thompson, 1992; Frymier \& Wanzer, 2006; Morgan \& Shim, 1990). Similarly, parental behaviors also influence child decisions and behaviors regarding their education (e.g., Dauber \& Epstein, 1993). Thus, given the relationship between parental behaviors and academic success, it seems clear that parental memorable messages about college will likely influence indicators of college success.

\section{Communication Behaviors Comprising College Student Success}

Typically, studies conceptualize "success" using single measures such as grade point average (GPA; e.g., McCroskey, Booth-Butterfield \& Payne, 1989) or college graduation (McCroskey et al., 1989). Although these measures reflect important goals of the college experience, examining multiple indicators of college success (i.e., cognitive learning indicators, college satisfaction, college motivation, and learner empowerment) may provide a more complete picture of how parental communication relates to college student success. Previous researchers suggested that each of these variables is related to more traditional measures of college success such as graduation rates, retention, and GPA (Okun \& Weir, 1990). Likewise, these indicators were predicted by communication behaviors and messages within the classroom and/or the family (e.g., Morgan \& Shim, 1990). Thus, by investigating cognitive learning indicators, college satisfaction, college motivation, and learner 
empowerment, the current study examined college student success in a multidimensional and communication-centered manner. The following section explicates the importance of each of these indicators of college student success.

College satisfaction. College satisfaction is a key outcome in higher education that is related to numerous variables such as quality of teaching, campus involvement, and motivation (Astin, 1993; Benjamin \& Hollings, 1997). Okun and Weir (1990) reported that, on average, students with higher rates of college satisfaction have higher GPAs and lower attrition rates. Ultimately, college satisfaction is related to numerous positive outcomes such as academic achievement (Astin, 1993), student growth, and retention (Morgan \& Shim, 1990); thus, it is an important part of college success.

Whereas teaching quality has been shown to impact how satisfied students are with the educational experience (Morgan \& Shim, 1990), researchers have not investigated the associations of student satisfaction with communication from other important publics. Parents are important contributors to their children's sense-making in general (e.g., Smith \& Butler Ellis, 2001), and thus parental messages may influence a student's sense-making toward college and, therefore, the satisfaction he/she feels regarding college. Sense-making researchers have found that the positive or negative frame that a family attaches to an experience is predictive of family and individual functioning (e.g., Koenig Kellas, 2005). For example, if parents tell their children that college is a wonderful experience, perhaps the students are more likely to enter college with a positive, hopeful attitude. Likewise, if parents motivate their children to work hard and get good grades, this may predict higher rates of motivation in students.

Student motivation. Conceptualized as any goal-directed behavior or energy to perform a task to achieve a goal (Schunk, 1990), another indicator of college success is student motivation. Motivation is an important indicator of college success in that it strongly predicts student learning (Richmond, 1990). If students are motivated to learn, they will work harder and achieve higher levels of learning. Although research suggests that teacher communication predicts student motivation (e.g., clarity, credibility, affinity-seeking, immediacy; Chesebro \& McCroskey, 2000; Christensen \& Menzel, 1998; Frymier \& Thompson, 1992) and that parental behavior and involvement predict child motivation (e.g., Grolnick \& Slowiaczek, 1994), the influence of parental messages in this process is still unclear. Grolnick and Slowiaczek (1994) found that parents' behavior and intellectual/cognitive involvement in their child's schooling predicted their child's motivational resources and school performance. Mothers' behaviors related to children's motivation through perceived competence and understanding of potential outcomes associated with one's actions (or control understanding), and fathers' behaviors related to motivation through perceived competence. Although parental communication has been theorized to be an important decision-making factor in children's education and career decisions (e.g., Lucas, 2011; Medved et al., 2006), researchers have not investigated the manner in which parental messages relate to children's educational success outcomes. Since motivation has been theorized to mediate the relationship 
between teacher communication behavior and student learning (Christophel, 1990; Frymier, 1994), it is imperative that scholars and instructors understand the multiple influences (e.g., parents) on student motivation. Overall, teacher behaviors are well-documented influencers of motivation in students, yet parent messages are also likely to be predictive of motivation.

Learner empowerment. Researchers have expanded traditional views of motivation to form the more learner-specific construct of learner empowerment (Frymier, Shulman, \& Houser, 1996). Learner empowerment addresses the extent to which students feel motivated and in control of their academic tasks, and is associated with cognitive learning and affective learning (Frymier et al., 1996; Weber, Martin, \& Patterson, 2001), positive adjustment to college, increased student motivation, and interest at the collegiate level (Pennebaker, Colder, \& Sharp, 1990). Frymier et al. (1996) suggested that interpersonal communication is the driving force behind students' sense of empowerment. Indeed, through communication, individuals gain a better understanding about their life experiences, which often leads empowerment over their stressors (Goldsmith, 2004). Parents give their children advice as a way to empower them to overcome their difficulties. In this way, parents' memorable messages may also empower students to make sense of and persevere in college.

Cognitive learning indicators. The final indicator of college student success in the current study is cognitive learning. Originating from research identifying specific behaviors and activities in which students engage while learning course content (Frymier et al., 1996), instructional scholars have measured cognitive learning by focusing on indicators such as asking questions, volunteering opinions, and discussing course content with others (Houser \& Frymier, 2009). Researchers have shown that discussion of course content and overall academics with family members and friends is positively related to cognitive learning (Houser \& Frymier, 2009) and cognitive complexity (Kuh, 1995). Further, cognitive learning indicators are associated with a variety of positive student outcomes including feelings of learner empowerment, affective learning, grades (Frymier \& Houser, 1999), motivation to learn (Frymier et al., 1996), overall college adjustment (Pennebaker et al., 1990), and satisfaction (Kuh, 1995).

Notably, researchers have found that adolescents are likely to turn to their parents in times of difficulty (Gardner \& Cutrona, 2004), such as struggling in a college class. These conversations may be a prime context for parental memorable messages. Further, memorable messages are theorized to aid individuals in decision-making and cognitive processing of confusing situations (Holladay, 2002; Smith \& Butler Ellis, 2001). As "important units of communication that potentially have a strong effect on ... sense-making processes" (Smith et al., 2009, p. 295), memorable messages may serve as a sense-making device in the classroom itself. Therefore, it stands to reason that parent-child discussions and memorable messages about college may contribute to their learning in the classroom.

Given the significant role of families in college student socialization and sensemaking (e.g., Medved et al., 2006) and the relationship between parental behaviors 
and student success (Chen et al., 2007; Cutrona et al., 1994; McKay et al., 2003), it is likely that parents' messages also play a role in student success. Memorable messages function to help students make sense of their college experience (Nanzione et al., 2001), and the way in which they do so is likely to predict their behaviors and thus success in college. Therefore, we posed the first hypothesis:

H1: Parental college memorable messages predict college success as indicated by cognitive learning, college satisfaction, college motivation, and learner empowerment.

Although memorable message content may predict college success, students' perception of the message-sender (i.e., the parent) will likely affect the way they receive the message. Considering the nature of the parent-child relationship is vital to understanding the impact the memorable message may have on the student. The parent-child relationship, like other interpersonal relationships, progresses through varying degrees of contentment that impact its development and maintenance (Vangelisti, 2006). Therefore, the extent to which parental memorable messages are impactful and important to students may be influenced by the satisfaction they feel in their parent-child relationship.

Relational satisfaction. Relational satisfaction relates to feelings of happiness and contentment with relational interactions (Dunleavy, Goodboy, Booth-Butterfield, Sidelinger, \& Banfield, 2009) and provides an assessment of partners' global feelings about the relationship (Fincham \& Beach, 2006). Given that disclosing information has been found to increase relational satisfaction (Derlega, Metts, Petronio, \& Margulis, 1993) among family members, it seems likely that memorable messages may function as a unique form of self-disclosure imparted from parents to their children. Students' perspectives of the relationship and message characteristics (such as its intent, degree of positivity, and the extent to which parents had their best interest in mind) may all influence the impact the message has on student success. In an effort to capture the complexity of college students' perceptions of parental memorable messages, we sought to understand how the relational context of the memorable message predicts student success. Thus, in order to extend this area of research between relational satisfaction, college student success, and memorable messages, our final hypothesis is:

H2: Relational satisfaction with the parent who provided the memorable message predicts college student success as indicated by cognitive learning, college satisfaction, college motivation, and learner empowerment.

\section{Method}

\section{Participants}

Participants included 419 students enrolled in a public university in the Midwestern United States who ranged in age from 19 to $44(M=20.49, S D=2.317)$. 
More than half the participants were male $(63 \%)$, and a majority were Caucasian $(89.6 \%, n=372)$, with 3.4\% $(n=14)$ African American, $2.9 \%(n=12)$ Asian, and $2.9 \%(n=12)$ Hispanic. An additional 2.2\% $(n=9)$ indicated 'other' or declined to indicate their ethnicity. The majority of students were sophomores $(44.7 \%, n=$ 187), $23.2 \%(n=97)$ were juniors, $16.7 \%(n=70)$ were seniors, and $15.1 \%(n=64)$ were first-year students. Students' self-reported cumulative mean GPA was 3.17 on a 4.0 scale $(S D=.51)$.

\section{Procedures}

Upon receiving human subjects board approval, the researchers recruited participants enrolled in communication courses. Interested students were provided with a link to an online informed consent form and web-based questionnaire on a volunteer basis. They were awarded minimal course credit (less than $2 \%$ ) for participation, and completed the questionnaire anonymously.

\section{Measures}

College memorable messages. Participants' memorable messages about college were elicited through an open-ended question on the online survey. Students were asked to report the "most memorable message that you can remember a parent telling you about college. This can be a message about going to college, succeeding in college, or any other circumstance surrounding college." In accordance with previous research on memorable messages (e.g., Catlett \& Koenig Kellas, 2009; Koenig Kellas, 2010; Lucas, 2011; Medved et al., 2006) a memorable message was conceptualized as "any verbal message that has had a lasting impression on you and which you perceive as having some sort of influence on you." Also consistent with the current literature on memorable messages (e.g., Catlett \& Koenig Kellas, 2009; Koenig Kellas, 2010), researchers provided participants with positively and negatively valenced examples of possible memorable messages such as "college was the best time of my life" and "there's no sense in going to college at all" to help participants to conceptualize their own memorable message.

College memorable message characteristics. Participants were also asked to rate on a 7-point Likert-type scale their perceptions of the memorable messages based on a series of question about characteristics of the message and their parent(s)' intent (e.g., Catlett \& Koenig Kellas, 2009; Koenig Kellas, 2010). These questions included the valence of the message, the extent to which the message was meaningful, and whether the parent(s) had their best interest in mind (e.g., "I feel that the content of this message was:" with $1=$ extremely negative, 5 = extremely positive; "I feel that hearing this message was:" with $1=$ extremely harmful, $5=$ extremely beneficial). Higher scores reflected a more positive affect toward the message.

Cognitive learning indicators. To assess students' cognitive learning, participants were asked to complete the Revised Learning Indicator Scale (Frymier \& Houser, 1999). This 13-item, 5-point Likert-type scale $(1=$ never, $5=$ very often $)$ 
contains items such as "I actively participate in class discussion" and "I review the course content" to assess how frequently students perform cognitive learning behaviors. Consistent with previous research on similar populations (Houser \& Frymier, 2009), the scale was found to be reliable $(\alpha=.83)$.

College motivation. Richmond's (1990) measure of motivation in the classroom was adapted to assess overall students' overall motivation about the college experience. Respondents were asked to indicate their feelings about college in response to five semantic differential items (e.g., "Motivated-Unmotivated," "Interested-Uninterested") using a 7-point response scale. Previous studies have shown this scale to be reliable ( $\alpha=.79-.94$; Richmond, 1990); it was also reliable in the current study $(\alpha=.90)$.

College satisfaction. An adapted version of Huston, McHale, and Crouter's (1986) Marital Opinion Questionnaire was used to access participants' college satisfaction in the past two months. The original scale was modified to measure students' recent feelings of satisfaction with their college experience. Ten of the items used seven-point semantic differential scales (e.g., Miserable-Enjoyable, Rewarding-Disappointing) and an additional item assessed global satisfaction in college using responses that ranged from (1) completely dissatisfied to (7) completely satisfied. This modified scale was reliable in the present study $(\alpha=.90)$.

Learner empowerment. Frymier et al.'s (1996) Learner Empowerment scale was used to assess students' perceptions of their overall empowerment on three dimensions: meaningfulness, impact, and competence. As suggested by Frymier et al. (1996), these three dimensions are positively correlated with each other and can be summed to create an overall empowerment measure, as was done in the present study. Participants indicated their level of empowerment on a 35-item, Likert-type scale $(1=$ never, 5 = always $)$ on items such as, "The tasks required in my classes are valuable to me," and "I make a difference in the learning that goes on in my classes." For the current study, the scale items were adapted to assess college classes globally rather than assessing particular college classes (Frymier et al., 1996). Consistent with previous studies of similar populations (e.g., Houser \& Frymier, 2009), the scale was found to be reliable $(\alpha=.91)$.

Relational satisfaction. Parental relational satisfaction was measured through an adapted version of Huston et al.'s (1986) Marital Opinion Questionnaire. This scale uses ten items on a 7-point differential scale to assess relational satisfaction, and one item on a 7-point differential scale to assess global relational satisfaction (see College Satisfaction, above). This scale was found to be reliable $(\alpha=.90)$.

\section{Data Analysis}

College memorable message themes. Inductive analysis was conducted by employing Owen's (1984) thematic analysis to unitize the data into themes. Inductive analysis allows the themes and subthemes to naturally emerge from the data 
(Strauss \& Corbin, 1998). To be considered a theme, a message must possess three criteria: (i) recurrence, or when different words could express the same idea or meaning, (ii) repetition, or when key words, sentences, or phrases were repeated explicitly and (iii) forcefulness, or when underlining, italicizing, bolding or increasing size of the text is found (Owen, 1984). The first two authors individually read the data in its entirety and generated broad categories emerging from the open-ended data. They then came together and engaged in constant comparative analysis, where they compared their themes to determine whether they represented similar or different meanings, establishing and reestablishing themes until they best represented the participants' messages (Strauss \& Corbin, 1998). The first two authors met with the third author and a research assistant to engage in negative case analysis, seeking to find data that contradicted the coding scheme (Bulmer, 1979).

Upon identification of the themes, a coding scheme was created consisting of explanations of each theme and subtheme. Five suprathemes (Work Hard and/or Play Hard, College is Necessary, My Two Cents, Support and Encouragement, and General Advice) consisting of eight themes were established. Once the coding scheme was created, a research assistant unaware of the current study's purpose was trained extensively on the coding procedures. The assistant received operational definitions and exemplars of the themes and then practiced coding the data. After the assistant and the first author achieved adequate reliability with each theme, each coded $50 \%$ of the data with $20 \%(n=87)$ in common. Reliability analyses using Cohen's kappa revealed good intercoder reliability $(\kappa=.86)$.

\section{Results}

\section{Memorable Message Themes}

The research question asked about the themes present in college students' memorable messages about college from their parents, revealing five suprathemes: Work Hard and/or Play Hard (WHPH), College is Necessary, My Two Cents, Support and Encouragement, and General Advice. The supratheme WHPH contained three themes: Work Hard, Balance Work and Play, and Play Hard. The supratheme My Two Cents contained two themes: Do This and Don't Do This. The suprathemes College is Necessary, Support and Encouragement, and General Advice did not contain separate themes (see Table 1 for frequencies and exemplars).

Work hard and/or play hard. Memorable messages with the Work Hard and/or Play Hard (WHPH) supratheme acknowledged the importance of focus on college, yet reflected varied opinions on the subject of focus. There were three subthemes within this supratheme:

Work hard. Many of the WHPH memorable messages emphasized the importance of students staying focused on their studies while in college. Many of them noted the "point" of college was to get good grades, study hard, and/or 
Table 1. College Memorable Message Themes

\begin{tabular}{|c|c|c|c|}
\hline Theme & Example & $N$ & $\%$ \\
\hline \multicolumn{4}{|c|}{ Work Hard Play Hard } \\
\hline Work Hard & $\begin{array}{l}\text { Get good grades. When you're graduated, it won't } \\
\text { matter what party you did or did not go to, the thing } \\
\text { that matters is your performance in school to help you } \\
\text { succeed in the real world. (3) }\end{array}$ & 60 & 14.3 \\
\hline Balance Work and Play & $\begin{array}{l}\text { Remember to have balance in your life. One needs to } \\
\text { have balance with their school work, classes, } \\
\text { involvement on campus and with the community and } \\
\text { social life. (309) }\end{array}$ & 45 & 10.7 \\
\hline Play Hard & $\begin{array}{l}\text { Don't let your studies get in the way of your college } \\
\text { career (7) }\end{array}$ & 86 & 20.5 \\
\hline College is Necessary & $\begin{array}{l}\text { My dad told me, 'The best thing you can do is get as } \\
\text { much education as you can because that opens doors } \\
\text { and allows you to do many different things' (16) }\end{array}$ & 58 & 13.8 \\
\hline \multicolumn{4}{|c|}{ My Two Cents: Other Advice for Attending College } \\
\hline $\begin{array}{l}\text { Do This: Providing } \\
\text { Advice for Good Decisions }\end{array}$ & Time-management is key! (307) & 72 & 17.2 \\
\hline $\begin{array}{l}\text { Don't Do This: Cautionary } \\
\text { Tales }\end{array}$ & $\begin{array}{l}\text { (My dad) told me that he wasted his first year by } \\
\text { partying too much and not paying attention in class or } \\
\text { giving it all he had at his athletics. He was on } \\
\text { scholarship and lost it because he failed to keep up the } \\
\text { standards that were set. This is something that has } \\
\text { haunted him, and he told me to just work hard } \\
\text { because you have the rest of your life to do what you } \\
\text { want. (133) }\end{array}$ & 22 & 5.3 \\
\hline $\begin{array}{l}\text { Support and } \\
\text { Encouragement }\end{array}$ & I'm proud of you, I know you will do great (90) & 41 & 9.8 \\
\hline General Advice & $\begin{array}{l}\text { My father told me about his experiences on the UNL } \\
\text { crew team that he was on when he was at college here. } \\
\text { Specifically, he would tell me about what it felt like to } \\
\text { be out on the lake at dawn in the boat. (135) }\end{array}$ & 27 & 6.4 \\
\hline
\end{tabular}

graduate, and minimized the idea that college is for life experience or for socializing. For example: "Just remember what you're there for. We want you to have fun but you're there for school first. You've got the rest of your life to be wild and crazy" (Participant \#120; subsequent citations will provide participant numbers only). These parents sought to motivate their children to "put [their] nose to the grind stone" (142).

Balance work and play. Some students noted that their parents encouraged them to balance the work and play present in college, acknowledging that both academics and social activities were important to the college experience. For example: "Remember to have balance in your life. One needs to have balance with their school work, classes, involvement on campus and with the community and social life" (309). Other parents acknowledged the importance of both work and play, but ultimately gravitated toward one pole: "Go to your classes, do your best, and spend more time studying than drinking" (63). 
Play hard. Whereas the Balance Work and Play messages acknowledged the ultimate importance of both academics and sociability, the Play Hard messages showed no interest in "having my nose in a book the entire time" (7). These parents saw college as a time for fun and exploration, not necessarily a time for serious work. Some of these messages had catchy phrases such as "Don't let your studies get in the way of your college career" (7) or "College will be some of the best times in your life" (163). Many of these messages stressed that college was a place for self-discovery. For example, one parent said, "College is a time to find yourself, meet new people, and have fun. Don't let the time go by fast; embrace it" (257). These parents seemed to excite their children about the social and "life" experiences that college often brings.

College as necessary. In these memorable messages, parents explained their perceptions of the necessity of college. Many mentioned the current state of the economy and the tough competition for securing employment, indicating that they felt a college education was mandatory for being competitive in the job market. Some parents noted that "times have changed" since their own college years, or that "nowadays you have to go to college to get a great job" (73). Other parents were generally positive in the messages and encouraged their children to perceive college as an opportunity for success: "College will give you the best opportunity to do the things you want to do in life, and be able to live the life you want to lead" (143).

My two cents: other advice for attending college. Many of the memorable messages were pieces of advice that parents instilled upon their child. The themes within this supratheme included:

Do this: providing advice for good decisions. In these memorable messages, parents gave advice that empowered their children to make decisions based on examples of past success. One parent said, simply, "Your education is what you make out of it" (160). Embedded within this message is the fact that students choose to make their education a positive or a negative experience. Some messages provided very specific advice about the "tricks" to college. For example, one participant's parent noted, "Time management is key!" (307). These types of messages provided the student with comfort in the face of difficulty and empowered them to grow from the experience.

Don't do this: cautionary tales. In contrast to the positive messages in the previous theme, messages containing Don't Do This are framed in a negative light. Parents told cautionary stories of their own and others' mistakes in college to warn students against making poor choices. These messages often related to the risky health behaviors more common in college student populations, including alcohol and/or drugs ("partying") and sex, and other behaviors such as dropping out of college. For example, "My mother didn't go to college right after high school, because she was pregnant with me, so she stresses the importance of being responsible and going to college right away and then starting a family" (371). Regret 
was a common theme in the messages involving anecdotes, where the parent regretted his/her decision and used this regret as a way to caution the child against the decision (see exemplar in Table 1).

Support and encouragement. In the previous suprathemes, parents provided advice on how to succeed in college or guiding them toward the path of a successful college career; in the Support and Encouragement supratheme, however, parents were fulfilling their children's emotional needs during their transition to college. In these memorable messages, parents sought to reassure their children of their love and support, and encouraged them to use their talents to be successful in college. These memorable messages use more emotion-laden words (e.g., "love," "support," "proud") than in the other memorable messages. Often, these messages were very warm, yet simple (e.g., "[We] love you, believe in you, and good luck," 272). It seemed that the parents were attempting to motivate their children, while also providing them a level of safety during the exciting yet intimidating time of college.

General advice. Some of the students' memorable messages about college were anecdotes, reflections, or other thoughts provided by their parents. These were often about their parents' college experience (e.g., "When I graduated I had at least 4 minors" [30]), whereas others were specific reflections about college (e.g., "You can either race a sprint car for a year or go to college" [85]). This general advice was important to the individual sense-making of the participants, yet did not fit the other categories established.

\section{Relationship Between Memorable Messages and College Outcomes}

The first hypothesis investigated the relationship between college memorable message themes and college motivation, college satisfaction, learner empowerment, and cognitive learning indicators. Descriptive statistics and Pearson's product-moment correlations for the indicators of college success in this study are provided in Table 2.

A MANOVA was used to examine the relationship between memorable message theme and college motivation, college satisfaction, learner empowerment, and cognitive learning indicators. The result of the multivariate test was not significant for memorable message theme, Pillai's Trace $=.11, F=1.11, d f=(1750)$,

Table 2. Descriptive Statistics and Pearson's Product-Moment Correlations for Relational Satisfaction and College Success Variables $(N=414)$

\begin{tabular}{llllllll}
\hline Variables & $M$ & $S D$ & 1 & 2 & 3 & 4 & 5 \\
\hline 1. Relational Satisfaction & 6.06 & .80 & - & & & & \\
2. College Satisfaction & 5.33 & .90 & $.31^{* *}$ & - & & & \\
3. College Motivation & 2.02 & .84 & $.36^{* *}$ & $.66^{* *}$ & - & & \\
4. Learner Empowerment & 3.33 & .45 & $.20^{* *}$ & $.55^{* *}$ & $.46^{* *}$ & - & \\
5. Learning Indicators & 3.39 & .49 & $.20^{* *}$ & $.46^{*}$ & $.52^{* *}$ & $.62^{* *}$ & - \\
\hline
\end{tabular}

$* * p<.01$ 
$p>.05$, indicating that college success did not vary as a function of the specific theme of the memorable message. Thus, H1 was not supported.

As follow-up analysis to the initial MANOVA results, we considered the overall valence of each memorable message theme. Participants framed the vast majority of these messages in a positive light, even when the content of the message included a cautionary tale about their parent's own mistakes during college. Yet, the student outcomes associated with these positive frames were not always positive. Thus, it seems likely that the students made sense of the (positive) content of the message in different and important ways. Given the significant positive correlations between students' relational satisfaction with their parent and all four indicators of college success (see Table 2), it is possible that students' interpretation of the message was a stronger predictor of college success than the theme

To test this line of reasoning, a series of regression analyses were conducted to assess the role of message characteristics in predicting college student success. Specifically, a mean composite score was created for the students' overall perception of the message characteristics. This score was comprising students' perceptions of the valence of the message, the message's meaningfulness, and parents' best interests in mind. Message characteristics $(M=4.46, S D=.61)$ emerged as a significant predictor of numerous aspects of college success. Specifically, message characteristics accounted for $3.5 \%$ of the variance in cognitive learning, $R=.18$, $F(1,403)=13.272$, and $5.3 \%$ of the variance in college motivation, $R=.23, F(1,406)$ $=21.66$, with both predictors significant at $p<.001$. Message characteristics also emerged as a significant predictor of overall college satisfaction, $R=.29, F(1,401)$ $=36.070, p<.001$ and, learner empowerment, $R=.28, F(1,375)=32.057, p<.001$, accounting for $8.4 \%$ and $7.8 \%$ of the variance, respectively. Overall, the results of this analysis for $\mathrm{H} 1$ indicate that college students' interpretation of their parents' memorable messages played a more significant role in predicting college success than did the content of the message itself.

The final hypothesis, $\mathrm{H} 2$, investigated whether relational satisfaction with the sender of the memorable message predicted indicators of college success. To test this hypothesis, hierarchical regression analyses were computed, positioning relational satisfaction as the predictor and indicators of college success as criterion variables. Because message characteristics were significantly correlated with relational satisfaction at the bivariate level, controlling for these characteristics isolated the effect of relational satisfaction on college success variables independent of message characteristics. Additionally, student sex was held constant in the final model as it was not a focal variable in the present study. With regard to cognitive learning, the overall model was significant $(R=.23, F(2,396)=11.38, p<$ $.001)$, accounting for $5.3 \%$ of the variance. After controlling for student sex and message characteristics, relational satisfaction emerged as a significant predictor of cognitive learning $(\beta=.158, t=3.012, p<.05)$. Similarly, relational satisfaction $(\beta=.226, t=4.421, p<.05)$ predicted college satisfaction in the final model $(R=$ $.40, F(2,394)=29.05, p<.001)$, accounting for $16 \%$ of the variance. The final model for college motivation was also significant $(R=.37, F(2,399)=31.20, p<.001)$, accounting for $13.7 \%$ of the variance, with relational satisfaction again emerging as a significant predictor $(\beta=.318, t=6.402, p<.05)$. Finally, relational satisfaction 
predicted learner empowerment $(\beta=.110, t=2.031, p<.05)$ after again controlling for sex and message characteristics $(R=.30, F(2,368)=17.52, p<.001)$. Overall, these results suggest that relational satisfaction with the parent providing memorable messages about college has a significant and unique effect on a variety of indicators of student college success.

\section{Discussion}

To understand the nuances of college student success, instructional communication researchers and educators must step outside the walls of academia to appreciate the experiences of their students (Sprague, 1992, 2002). In the current study, we addressed this contention by examining the ways in which parent-child relationships shape individuals' worldviews and understanding of college. In the current study, qualitative memorable message themes paint a picture of college talk between parents and children, while also highlighting the significant relationship between message and sender characteristics and student success. The quantitative results contextualize the meaning behind the themes explicated from the qualitative data.

Overall, we discovered two overarching findings about the interplay of parental memorable messages and college student success. First, our findings indicated that college students do receive and remember messages from their parents on a variety of topics, such as Work Hard and/or Play Hard, College is Un/Necessary, My Two Cents, Support and Encouragement, and General Advice. Second, although these specific message themes were unrelated to student success, the message characteristics and relational satisfaction with the message-provider emerged as significant predictors of student outcomes. Thus, the relational context surrounding the message was a more robust predictor of college student success than the content of the message itself. To further explore these findings, we will examine the message themes and their outcomes, articulate potential implications of these findings, and finally discuss limitations and future research.

\section{College Memorable Message Themes and Findings}

By investigating a variety of qualities of the messages that have been memorable and important to college students, we assessed how memorable messages facilitate students' sense-making about college. We will first explicate the general qualities and themes of the memorable messages, and then explain the connection between these messages and student outcomes.

College memorable message themes. Consistent with Knapp and colleagues' (1981) findings on memorable messages, the themes that emerged in the present study were largely positive, supportive, global (i.e., applicable in most situations, rather than specific to the students' experiences), and action-oriented (rather than passive remarks about how the world operates). Parents seemed to be providing positive advice and support through these messages and 
generally understood the emotional needs of their college student children. For example, in the most frequent type of message, Work Hard and/or Play Hard (WHPH), parents helped to direct students to the appropriate or ideal approach to college. The Support and Encouragement theme also focused on family support during a time of exploration and growth. These messages associated with the importance of identity exploration are consistent with theorizing on psychological and emotional development in young adulthood (Rosenberg, 1985). During their college years, students experience a time of self-discovery in which identity formation is paramount (Ellis, 2004). Although Ellis focused on the teacher's role in this process, our study suggest that parents also seem to recognize their child's life transition and are helping them make sense of that process. Further support for WHPH and Support and Encouragement is found in Nanzione and colleagues' (2001) findings, stating that "Believe in Yourself" and "Work Hard" were the two most common memorable messages about college themes cited from students.

In another positively charged message, College as Necessary, parents focused on helping the students make sense of their experience in light of recent economic changes. This theme is timely for the college student population given the fervor surrounding the current state of the global economy and the job market; indeed, the U.S. unemployment rate for high school graduates was $10.9 \%$, whereas the rate of unemployment for those with college degrees was just 5.5\% (Bureau of Labor Statistics, 2011). Only five participants cited messages of ambivalence or negativity toward college (e.g., "You can always come back home and farm later, but you need to stay in college and get a degree so you have something to fall back on" [183]). This finding is consistent with previous research on career-related messages from blue-collar parents, which stated that messages focusing on reproducing parents' blue collar careers were delivered in implicit ways, rather than through direct messages (Lucas, 2011). Thus, perhaps college students are receiving negative messages about college through more implicit, rather than direct messages.

Whereas most of the messages parents provided their children were positive in nature, one memorable message theme that contained threads of negativity was Don't Do This: Cautionary Tales. Similarly to Koenig Kellas' (2010) Warning theme in romantic relationship memorable messages, parents used cautionary stories to warn children of the harmful consequences of poor choices in college. For example, one participant told the following story: "My mother explained to me the importance of planning before a test. Her roommate stayed up all night studying for her finals and even took No-Doz so she could stay awake. Once she arrived for the final, she passed out due to sleep deprivation" (383). These cautionary tales are used to socialize family members into making appropriate choices in difficult situations (Stone, 1988).

Overall, findings about the nature of students' parental memorable messages illuminate the specific messages about college that children receive from their parents. The content of the message had been theorized to also influence student behavior (Nanzione et al., 2001), yet this assumption had not been empirically tested. Thus, the current study expanded researchers' understanding of college 
memorable messages by investigating the relationship between parental messages and college student success.

College memorable messages and student success. Although existing research has indicated that $90 \%$ of people believe memorable messages have a positive effect on their lives (Knapp et al., 1981), the current study's findings demonstrate that memorable message themes may not function in the direct linear way previously assumed. Memorable messages themes were important and accessible to students, but the content of specific themes did not significantly predict student success. However, message characteristics (e.g., valence, perception of parent intent) and relational satisfaction with the message-provider (i.e., the parent) were predictive of student outcomes of college motivation, college satisfaction, learner empowerment, and cognitive learning indicators. This finding is consistent with Catlett and Koenig Kellas' (2009) results of the importance of message valence in predicting participant outcomes. Notably, the student success outcome variables were positively correlated with one another, indicating that each of these "success" qualities works in conjunction with the others. Despite the interrelation of the outcome variables, student perception of their parents and parental messages were independently predictive of each of the student outcome measures-college satisfaction, motivation, cognitive learning, and learner empowerment.

College satisfaction depends in part on one's perception of overall sense-making of the college experience, and the current study's findings show that students' positive perceptions of their parents and parents' messages relate to positive perceptions of school. Thus, perhaps children learn how to make sense of the college experience based on the overall sense-making in their families. These findings are reasonable given that the way in which individuals and families make sense of their lives predict individual well-being and functioning (Koenig Kellas, 2005; McAdams, 1993). Thus, if students feel positively about the relationships and messages they hear at home, they may be more likely to frame their new college experience in a similarly positive way.

Perceptions of memorable messages and parent relationships were also predictive of both college student motivation and empowerment. This finding extends previous instructional research by examining the relationship between parental communication and motivation, and specifically learner empowerment in college students. Researchers have found that parents' behavior and involvement predicted young children's motivation in school (Grolnick \& Slowiaczek, 1994), yet we were largely unaware of the connection between parental communication and college student motivation. Results from the current study attest to the importance of an overall positive home environment for college student success. When college students report higher rates of parental satisfaction and positive perceptions of parental messages, they are more likely to be more motivated and empowered to achieve in college. This finding has important implications for instructional researchers finding that motivation mediates the relationship between teacher communication behavior and student learning (Christophel, 1990; Frymier, 1994). These findings support the argument that teachers can influence 
student motivation and empowerment in part, but parental communication contributes to these student qualities as well.

Finally, findings from the current study speak to the association of relational satisfaction and message characteristics on college student cognitive learning. These results show that a positive parental relationship and perception of parental messages is associated with student learning behaviors. This finding extends current literature that illuminated the association between parental behavior and child academic achievement (e.g., Alwin \& Thornton, 1984) by focusing on the importance of the parent-child relationship. Additionally, this finding raises questions about the role of family communication in overall student learning. Notably, as found in past research and echoed in the current study, cognitive learning indicators are related with student outcomes such as grades (Frymier \& Houser, 1999), motivation to learn (Frymier et al., 1996), and college adjustment (Pennebaker et al., 1990). Thus, future research should investigate the direct and indirect effects of parental communication on student learning. Does parental communication directly influence cognitive learning, or does cognitive learning increase by way of student variables such as motivation? The current study helps to build the foundation for deeper investigation into the effects of parental communication on student achievement.

\section{Implications of Findings}

The theoretical implications of these results extend knowledge of the student experience for instructional and family communication researchers, and point to the potential for both areas to increase our understanding of the complexities within the instructional context. Specifically we present three overarching explanations for the current study's findings. First, these findings demonstrate the complexity of memorable messages and their relationship to individual behavior. Past researchers hypothesized that although memorable messages are remembered in a linear fashion, they actually function in more nuanced ways: "When these messages are remembered, the reasons are complex and involve the nature of the recipient, the sender, and the message" (Knapp et al., 1981, p. 34). Given that message and sender characteristics were significantly predictive of student outcomes in the current study, the implied nature of a message seems to be more important to the student's success than its actual content or theme. For example, messages such as Work Hard could be interpreted as supportive or oppressive: "The smartest do not always have the most success, it's (sic) the people who want it the most" (2). Measuring the participants' perspectives of the message, researchers access the most important element of the message: sense-making.

Second, although parents are highly influential to children's decisions at young ages (Gardner \& Cutrona, 2004), college students may be more likely to seek individuation from their parents and thus turn away from parental advice (Goldsmith, 2004). Researchers studying advice have found that individuals respond to advice in varying ways (Cutrona \& Suhr, 1994; Goldsmith, 2004). Thus, although the students retain their parents' advisory messages, they may not always adhere to that advice. 
Third, although these findings are consistent with previous research (e.g., Catlett \& Koenig Kellas, 2009), it appears that the content of a memorable message may not be as important as the context in which it was given. Because the memorable message content was not significantly related to college success but relationship and message satisfaction are significant predictors, the relational context of the message is perhaps more important than the message itself. The current study's memorable messages were given within the context of the family, a communicatively complex and influential setting. Past research has indicated that the family communication culture and patterns are significant predictors of child sense-making and well-being (e.g., Koerner \& Fitzpatrick, 1997; Schrodt \& Ledbetter, 2007). For example, family conversation orientation is directly related to better mental well-being in young adults (Schrodt \& Ledbetter, 2007). Thus, perhaps the overall communication context of the family moderates the relationship between message characteristics and child success and well-being. In a family high in conversation orientation (e.g., a climate that discourages openness of dialogue), a message of "work hard" may be followed with an explanation of how working hard might be beneficial to a child's future. Contrastingly, a message of "work hard" in a conformity-oriented family (e.g., a climate that discourages openness of dialogue) may send a more dictatorial or oppressive message without any supportive explanation. Future research should study the moderating effects of relational satisfaction and college student success, particularly in at-risk groups. For students who are less likely to succeed in college, perhaps a satisfying parent relationship and positive messages can help mitigate their risk of attrition.

Practical implications for educators and parents. Clearly, memorable messages about college are important and useful to college students, with far-reaching applications for both educators and parents. Instructors may be able to tap into their students' memorable messages by incorporating self-reflective assignments, activities, and discussions as a means to create relevance and affect towards course content. In addition, giving voice to students' experiences allows educators the opportunity to create learner-centered classrooms (Palmer, 1998), and to work from a place of understanding regarding the messages that students received before walking into their classroom. Reflecting the students' parental memorable messages may increase students' perception of course relevancy and potentially increase student motivation (Muddiman \& Frymier, 2009).

The current study's findings also have implications for parents of college students. Because the content of the message appeared to be less important than its intent, positivity, and overall relational health, cultivating the parent-child relationship will benefit students more than knowing the "words to say" when providing advice for a student's transition into college. College professionals may use this information when talking with parents at new student orientation programming by educating parents on the importance of the overall parent-child relationship, more so than the actual words used. 
Limitations and future research. This study contributes to the theoretical and practical understanding of the relationship between parental socialization and college student success, yet a few limitations must still be considered. Despite drawing from a relatively large sample of students $(n=419)$, a more diverse sample of student and parent characteristics would further our understanding of the memorable messages given to first-generation students, students of varying races, ethnicities, backgrounds, and socioeconomic status, and student-athletes. Collecting memorable messages from various types of students and families will provide educators with information on the way these families help their children make sense of this stressful time of transition into college.

Although our intent was to understand the experiences of current college students and their success, it may also be useful to expand beyond the traditional college student population. For example, investigating the differences between those who complete college and those who do not, as well as those between traditional and nontraditional students, may illuminate the message characteristics predictive of student graduation versus attrition. What types of messages predict student attrition or failing grades? What are the negative outcomes of memorable messages?

In conclusion, in the current study we analyzed the memorable messages that college students cite from parents and found that characteristics of these messages predict college student success. This study contributes to the knowledge on college student outcomes in providing voice to students' experiences outside of the classroom and demonstrates a need for investigating students' sense-making in relation to their college experience.

\section{References}

Alwin, D. F., and Thornton, A. (1984). Family origins and the schooling process: Early versus late influence of parental characteristics. American Sociological Review, 49, 784-802.

Astin, A. W. (1993). What matters in college? Four critical years revisited. San Francisco: Jossey-Bass.

Benjamin, M., and Hollings, A. (1997). Student satisfaction: Test of an ecological model. Journal of College Student Development, 38, 213-228.

Bulmer, M. (1979). Concepts in the analysis of qualitative data. Sociological Review, 27, 651-677.

Bureau of Labor Statistics (2011). Economic news release: Table A-4. Employment status of the civilian population 25 years and over by educational attainment. Retrieved from http://www.bls.gov/news.release/empsit.t04.htm

Catlett, J., and Koenig Kellas, J. (2009, February). "Looks like you've gained the freshman fifteen already!" Investigating the links between memorable messages received from family members and body image satisfaction. Paper presented at the annual meeting of the Western States Communication Association, Mesa, AZ.

Cauce, A., Hannan, K., and Sargeant, M. (1992). Life stress, social support, and locus of control during early adolescence: Interactive effects. American Journal of Community Psychology, 20, 787-797.

Chen, H., Yu, C., and Chang, C. (2007). E-homebook system: A web-based interactive education interface. Computers and Education, 49, 160-175. 
Chesebro, J. L., and McCroskey, J. C. (2000). The relationship between students' reports of learning and their actual recall of lecture material: A validity test. Communication Education, 49, 297-301.

Christensen, L. J., and Menzel, K. E. (1998). The linear relationship between student reports of teacher immediacy behaviors and perceptions of state motivation, and of cognitive, affective and behavioral learning. Communication Education, 47, 82-90.

Christophel, D. M. (1990). The relationships among teacher immediacy behaviors, student motivation and learning. Communication Education, 47, 82-90.

Cutrona, C. E., Cole, V., Colangelo, N., Assouline, S. G., and Russell, D. W. (1994). Perceived parental social support and academic achievement: An attachment theory perspective. Journal of Personality and Social Psychology, 66, 369-378.

Cutrona, C. E., and Suhr, J. A. (1994). Social support communication in the context of marriage: An analysis of couples' supportive interactions. In B. R. Burleson and T. L. Albrecht (eds.), Communication of social support: Messages, interactions, relationships, and community (pp. 113-135). Newbury Park, CA: Sage.

Dauber, S. L., and Epstein, J. L. (1993). Parents' attitudes and practices of involvement in inner-city elementary and middle schools. In N. F. Chavkin (ed.), Families and schools in a pluralistic society (pp. 53-71). New York: State University of New York Press.

Derlega, V. J., Metts, S., Petronio, S., and Margulis, S. T. (1993). Self-disclosure. London: Sage.

Desmione, L. (1999). Linking parental involvement with student achievement: Do race and income matter? Journal of Educational Research, 93, 11-30.

Docan-Morgan, and Manusov, V. (2009). Relational turning point events and their outcomes in college teacher-student relationships from students' perspectives. Communication Education, 58, 155-168.

Dunleavy, K., Goodboy, A., Booth-Butterfield, M., Sidelinger, R., and Banfield, S. (2009). Repairing hurtful messages in marital relationships. Communication Quarterly, 57, 67-84.

Eckel, P. (1994, July). Building community in the freshman and senior year experiences: Completing the cycle of student-institution involvement. Paper presented at the International Conference of the First Year Experience. Retrieved from http://eric.ed.gov/PDFS/ ED372701.pdf

Ellis, K. (2004). The impact of perceived teacher confirmation on receiver apprehension, motivation, and learning. Communication Education, 53, 1-20.

Fincham, F. D., and Beach, S. R. (2006). Relational satisfaction. In A. K. Vangelisti and D. Permlan (eds.), The Cambridge handbook of personal relationships (pp. 579-594). New York: Cambridge University Press.

Fitzpatrick, M. A., and Caughlin, J. P. (2002). Interpersonal communication in family relationships. In M. L. Knapp and J. A. Daly (eds.), The handbook of interpersonal communication (pp. 726-777). Thousand Oaks, CA: Sage.

Frymier, A. B. (1994). A model of immediacy in the classroom. Communication Quarterly, $42,133-144$.

Frymier, A. B., and Houser, M. L. (1999). The revised learning indicators scale. Communication Studies, 50, 1-12.

Frymier, A. B., and Houser, M. L. (2000). The teacher-student relationship as an interpersonal relationship. Communication Education, 49, 207-219.

Frymier, A. B., Shulman, G. M., and Houser, M. L. (1996). The development of a learner empowerment measure. Communication Education, 45, 181-199.

Frymier, A. B., and Thompson, C. A. (1992). Perceived teacher affinity-seeking in relation to perceived teacher credibility. Communication Education, 41, 388-399.

Frymier, A. B., and Wanzer, M. B. (2006). Teacher and student affinity-seeking in the classroom. In T. P. Mottet, V. P. Richmond, and J. C. McCroskey (eds.), Handbook of instructional communication: Rhetorical and relational perspectives (pp. 195-211). Boston, MA: Allyn and Bacon. 
Galvin, K. (2003). International and transracial adoption: A communication research agenda. Journal of Family Communication, 3, 237-254.

Gardner, K. A., and Cutrona, C. E. (2004). Social support communication in families. In A. Vangelisti (ed.), Handbook of family communication (pp. 495-512). Mahwah, NJ: Erlbaum.

Goldsmith, D. J. (2004). Communicating social support. New York: Cambridge University Press.

Griffith, J. (1996). Relation of parental involvement, empowerment, and school traits to student academic performance. Journal of Educational Research, 90, 33-41.

Grolnick, W. S., and Slowiaczek, M. L. (1994). Parents' involvement in children's schooling: A multidimensional conceptualization and motivational model. Child Development, $65,237-252$.

Holladay, S. J. (2002). "Have fun while you can," "You're only as old as you feel" and "Don't ever get old!": An examination of memorable messages about aging. Journal of Communication, 52, 681-697.

Hoover-Dempsey, K. V., and Sander, H. M. (1995). Parental involvement in children's education: Why does it make a difference? Teachers College Record, 97, 310-331.

Hosek, A., and Thompson, J. (2009). Communication privacy management and college instruction: Exploring the rules and boundaries that frame instructor private disclosures. Communication Education, 58, 327-349.

Houser, M. L., and Frymier, A. B. (2009). The role of student characteristics and teacher behaviors in students' learner empowerment. Communication Education, 58, 35-53.

Huston, T. L., McHale, S. M., and Crouter, A. C. (1986). When the honeymoon's over: Changes in the marriage relationship over the first year. In R. Gilmour and S. Duck (eds.), The emerging field of personal relationships (pp. 109-132). Hillsdale, NJ: Erlbaum.

Immerwahr, J., Johnson, J., Ott, A., and Rochkind, J. (2010). Squeeze play 2010: Continued public anxiety on cost, harsher judgments on how colleges are run. Public Agenda for the National Center on Public Policy and Education. Retrieved from http://www.highereducation.org

Knapp, M., Stohl, C., and Reardon, K. (1981). Memorable messages. Journal of Communication, 31, 27-41.

Koenig Kellas, J. (2010). Transmitting relational world views: The relationship between mother- daughter memorable messages and adult daughters' romantic relationship schemata. Communication Quarterly, 58, 458-479.

Koenig Kellas, J. (2005). Family ties: Communicating identity through jointly told stories. Communication Monographs, 72, 365-389.

Koerner, A. F., and Fitzpatrick, M. A. (1997). Family type and conflict: The impact of conversation orientation and conformity orientation on conflict in the family. Communication Studies, 48, 59-75.

Kuh, G. D. (1995). The other curriculum: Out-of-class experiences associated with student learning and personal development. Journal of Higher Education, 66, 123-155. doi: $10.2307 / 2943909$

Lucas, K. (2011). Socializing messages in blue-collar families: Communicative pathways to social mobility and reproduction. Western Journal of Communication, 75, 95-121.

McAdams, D. P. (1993). The stories we live by: Personal myths and the making of the self. New York: Guilford.

McCroskey, J. C., Booth-Butterfield, S., and Payne, S. K. (1989). The impact of communication apprehension on college student retention and success. Communication Quarterly, 37, 100-107.

McKay, M. M., Atkins, M. S., Hawkins, T., Brown, C., and Lynn, C. J. (2003). Inner-city African American parental involvement in children's schooling: Racial socialization and social support from the parent community. American Journal of Community Psychology, 32, 107-114. 
Medved, C. E., Brogan, S. M., McClanahan, M. A., Morris, J. F., and Shepherd, G. J. (2006). Family and work socializing communication: Messages, gender and ideological implications. Journal of Family Communication, 6, 161-180.

Morgan, G., and Shim, S. (1990). University student satisfaction: Implications for department planning. Home Economics Research Journal, 19, 47-66.

Mottet, T. P., Martin, M. M., and Myers, S. A. (2004). Relationships among perceived instructor verbal approach and avoidance relational strategies and students' motives for communicating with their instructors. Communication Education, 53, 116-122.

Muddiman, A., and Frymier, A. B. (2009). What is relevant? Student perceptions of relevance strategies in college classrooms. Communication Studies, 60, 130-146.

Nanzione, S., Laplante, C., Smith, S. W., Cornacchione, J., Russell, J., and Stohl, C. (2001). Memorable messages for navigating college life. Journal of Applied Communication Research, 39, 123-143.

National Center for Education Statistics. (2008). The Condition of Education 2008. U. S. Department of Education. Retrieved from http://nces.ed.gov

Okun, M. A., and Weir, R. M. (1990). Toward a judgment model of college satisfaction. Education Psychology Review, 2, 59-76.

Owen, W. (1984). Interpretive themes in relational communication. Quarterly Journal of Speech, 70, 274-287.

Palmer, P. (1998). The courage to teach: Exploring the inner landscape of a teacher's life. San Francisco: Jossey-Bass.

Pennebaker, J. W., Colder, M., and Sharp, L. K. (1990). Accelerating the coping process. Journal of Personality and Social Psychology, 58, 528-537.

Richmond, V. P. (1990). Communication in the classroom: Power and motivation. Communication Education, 39, 181-195.

Rosenberg, M. (1985). Self-concept and psychological well-being in adolescence. In R. L. Leahy (ed.), The development of self (pp. 205-242). Orlando, FL: Academic Press.

Schrodt, P., and Ledbetter, A. M. (2007). Communication processes that mediate family communication patterns and mental well-being: A means and covariance structures analysis of young adults from divorced and non-divorced families. Human Communication Research, 33, 330-356.

Schunk, D. H. (1990). Introduction to the special section on motivation and efficacy. Journal of Educational Psychology, 82, 3-6.

Smith, S. W., and Butler Ellis, J. (2001). Memorable messages as guides to self-assessment behavior: An initial investigation. Communication Monographs, 68, 154-168.

Smith, S. W., Nazione, S., LaPlante, C., Kotowski, M., Atkin, C., Skubisz, C., and Stohl, C. (2009). Topics and sources of memorable breast cancer messages and their impact on prevention and detection behaviors. Journal of Health Communication, 14, 293-307.

Sprague, J. (1992). Expanding the research agenda for instructional communication: Raising some unasked questions. Communication Education, 41, 1-25.

Sprague, J. (2002). The spiral continues. Communication Education, 51, 337-354.

Stone, E. (1988). Black sheep and kissing cousins: How our family stories shape us. New York: Penguin Books.

Strauss, A., and Corbin, J. (1998). Basics of qualitative research: Techniques and procedures for developing grounded theory (2nd ed.). Thousand Oaks, CA: Sage.

Thorkildsen, R., and Stein, R. S. (1998). Is parent involvement related to student achievement? Exploring the evidence. Research Bulletin, 22, 17-20.

Vangelisti, A., Crumley, L., and Baker, J. (1999). Family portraits: Stories as standards for family relationships. Journal of Social and Personal Relationships, 16, 335-368.

Vangelisti, A. L. (2006). Family communication theories: Variations and challenges. In D. O. Braithwaite and L. A. Baxter (eds.), Engaging theories in family communication: Multiple perspectives (pp. xi-xviii). Thousand Oaks, CA: Sage.

Weber, K., Martin, M. M., and Patterson, B. R. (2001). Teacher behavior, student interest, and affective learning: Putting theory into practice. Journal of Applied Communication Research, 29, 71-90. 